\title{
Government Procurement with Strings Attached: The Uneven Control of Offsets by the World Trade Organization and Regional Trade Agreements
}

\author{
David COLLINS* \\ City, University of London, United Kingdom \\ david.collins.1@city.ac.uk
}

\begin{abstract}
This paper explores the practice of governments imposing domestic content-based requirements known as "offsets" on suppliers in order to secure public procurement contracts. Known to cause distortions in international trade, offsets are forbidden under the WTO's Government Procurement Agreement and in the procurement chapters of several RTAs, although these restrictions have severe limitations with full offset prohibitions only accepted by a handful of developed countries. Given the sensitivity of procurement policy and the need to stimulate local economies, Asian countries in particular show an unwillingness to address offsets in their international agreements. While other WTO agreements restrain the use of local content rules, these regimes are ill-suited to control the harmful effects of offsets in a procurement context because of their focus on traditional commercial markets. The paper suggests that an enlargement of offset prohibitions would be advisable given the expected expansion of global procurement markets commensurate with economic development.
\end{abstract}

Government procurement, meaning the purchasing of goods and services directly by public bodies, is a significant component of the global economy, accounting for between ten and fifteen percent of national GDP on average and markedly higher for developed countries. Rising infrastructure spending in many emerging markets, bolstered by new development finance initiatives such as the BRICS Bank, suggests that procurement will play an increasingly important role in the coming decades. ${ }^{\mathrm{I}}$ Given its size, and the global nature of many firms capable of supplying government needs, government procurement also represents an economic activity that is highly susceptible to harmful distortions through discriminatory policies. Specifically, governments that

\footnotetext{
* Professor of International Economic Law, City, University of London.

I. R.M. DESAI and J.M. VREELAND, "What the New BRICS Bank is All About" (20I4) Washington Post, online: <https:/www.washingtonpost.com/news/monkey-cage/wp/2014/o7/I $7 /$ what-the-new-bankof-brics-is-all-about> (last accessed 3 November 2016).
} 
choose to impose domestic content requirements on suppliers without regard to quality or price can drain public resources, just as firms can end up spending more than needed to satisfy tender preferences. The rectification of these inefficient procurement practices, known as "offsets", is one of the most important but often overlooked aims of the World Trade Organization's [WTO] Government Procurement Agreement [GPA] ${ }^{2}$ and the procurement chapters of some Regional Trade Agreements [RTAs].

Following a brief illustration of the phenomenon of offsets in this introductory section, Part I of this paper will consider the extent to which procurement offsets are regulated under the WTO's GPA, including available exceptions for developing countries, national security, and general public interest matters. Part II will consider the possibility of controlling offset usage through two other WTO agreements, the Agreement on Trade-Related Investment Measures [TRIMs] ${ }^{3}$ and the Agreement on Subsidies and Countervailing Measures $[\mathrm{SCM}],{ }^{4}$ noting the inapplicability of these agreements to the non-commercial environment of public contracting. Part III will turn to offset controls in the procurement chapters of some RTAs, observing the unfortunately incomplete response of many of these agreements, particularly in the developing world. The paper will conclude by recommending a more expansive control of offsets under international law.

Before embarking on the analysis of offset controls in international trade law, it is apposite to explain precisely what is meant by an offset. Offsets are conditions imposed by governments on supplying firms essentially as means to ensure a degree of local content or local participation. They are therefore tools for stimulating national economies, often in conjunction with a development strategy. For supplying firms, offsets constitute additional conditions set out in tender documentation that are not directly related to the relevant procurement. In one sense offsets may be viewed as discriminatory as they elevate domestic goods and services above those which are produced internationally. However, offsets do not necessarily aim to exclude foreign bidders-all bidders in the procurement process are made subject to the same offset conditions regardless of their national origin. In this sense they are not inherently discriminatory. ${ }^{5}$

Specific definitions for offsets in the context of public procurement can be found in international instruments regulating this sphere of economic activity. These definitions commonly refer to offsets as conditions placed on a wide variety of commercial as well as procurement contracts. Using the equivalent language of "countertrade" measures, the United Nations Conference on International Trade Law [UNCITRAL] has defined offsets as "those transactions in which one party supplies goods, services, technology

2. Agreement on Government Procurement, 1994 (entered into force I January I996), online: World Trade Organization <https://www.wto.org/english/docs_e/legal_e/gpr-94_e.pdf> [1994 GPA].

3. Agreement on Trade-Related Investment Measures, I 5 April I994, I 868 U.N.T.S. I 86 (entered into force I January 1995), online: World Trade Organization <https://www.wto.org/english/docs_e/legal_e/ I 8-trims.pdf> [TRIMs].

4. Agreement on Subsidies and Countervailing Measures, I 5 April I994, I867 U.N.T.S. I4, online: World Trade Organization <https://www.wto.org/english/docs_e/legal_e/24-scm.pdf> [SCM].

5. Anna C. MULLER, "Special and Differential Treatment and Other Special Measures for Developing Countries under the Agreement on Government Procurement: The Current Text and New Provisions" in Sue ARROWSMITH and Robert D. ANDERSON, eds., The WTO Regime on Government Procurement: Challenge and Reform (Cambridge: Cambridge University Press, 20I I), at 36I. 
or other economic value to the second party, and in return, the first party purchases from the second party an agreed amount of goods, services, technology or other economic value". ${ }^{6}$ In the government procurement context, which is the focus of this paper, the purchasing party is always a government or other public authority.

Originally associated with the defence sector of North Atlantic Treaty Organization [NATO] countries, offsets became a fixture of international trade by the mid-I980s, with a number of countries applying them as a matter of course in procurement activities. This practice has now become widespread, with more than I 30 national governments engaging in offsets in one form or another. ${ }^{7}$ Korea in particular is known to impose high offset demands, with these requirements increasing from thirty to sixty percent of a contract's full value. ${ }^{8}$ In most circumstances a firm's offset obligation is worth between fifty and one hundred percent of the total value of the contract. This value is allegedly passed on to the procuring country in the form of economic benefits. The fulfilling of offset obligations is a key aspect of many firm's strategy in securing international contracts, particularly in lucrative infrastructure and defence projects. The size of the global offset market is thought to be more than US\$75 billion per year, with expectations that it will balloon to as much as US\$500 billion within the next decade. ${ }^{9}$

Procurement offsets are generally viewed as inefficient and counter-productive, diverting trade away from highest value uses. Rather than compete on the basis of the price and quality of their goods and services, suppliers win procurement contracts because of their degree of local content, even where this involves governments purchasing equipment or services it does not need or, more likely, pays more than is necessary to obtain the goods and services because of the offset terms, a clear welfare loss. At the same time, benefits which may be incurred by the domestic economy are difficult to quantify, in part because offset agreements are often spread over many years, and may be characterized as more political (satisfying particular constituents) than economic (benefiting the general public). The actual impact of offsets in terms of job creation or diversion, technology transfer, and increased international competitiveness of the domestic industry tends to be much smaller than expected. ${ }^{\text {IO }}$ In addition to their dubious economic benefits and their distortive effects on international trade, offset arrangements are viewed as a form of bribery, and are associated with corruption, particularly when negotiations are initiated by suppliers rather than governments. ${ }^{\text {II }}$ Data on offsets, especially in relation to defence contracts, are

6. UNCITRAL Legal Guide on International Countertrade Transactions (I993) at 5, online: <https://www. uncitral.org/pdf/english/texts/sales/countertrade/countertrade-e.pdf $>$ (last accessed 3 November 20I6).

7. Mark J. NACKMAN, “Critical Examination of Offsets in Defense Procurement: Policy Options for the United States” (20IO-II) 40 Public Contract Law Journal 5 I I at 5 I 6.

8. Ryan J. LAMBRECHT, "The Big Payback: How Corruption Taints Offset Agreements in International Defense Trade" (2013) 70 Air Force Law Review 73 at 76.

9. Carola HOYOS, Daniella TSAR, and Antoine AMANN, “Q\&A: What are Offsets?" Financial Times (9 October 20I3), online: <https://www.ft.com/content/87728d1e-I97a-I Ie3-afc2-ooI44feab7de> (last accessed 3 November 20I6).

Io. Baudoin HEUNINCK, "Security of Supply and Offsets in Defence Procurement: What's New in the EU?" (20I4) 2 Public Procurement Law Review 22 at 36.

II. Travis K. TAYLOR, "Countertrade Offsets in International Procurement: Theory and Evidence" in Murat A. YULEK and Travis K. TAYLOR, eds., Designing Public Procurement Policy in Developing Countries (New York: Springer, 2012). 
troublingly scarce. Few firms report these expenses to their shareholders, and countries are reluctant to publicize such arrangements. Accordingly, the magnitude of offsets may be considerably more than is realized. ${ }^{\mathrm{I} 2}$ It is important to recognize that some studies have shown that certain types of offsets can be economically advantageous for less advanced countries, in some cases contributing to knowledge transfer and other efficiency gains. ${ }^{\mathrm{I} 3}$ Their potential for welfare-enhancement is undoubtedly one of the reasons that offsets have persisted as a policy tool in many countries.

Despite the acknowledged harm of domestic content rules in procurement policies, there has been limited academic legal commentary on the use of offsets. Much of the existing discussion of procurement offsets relates to the exceptions found in many national and international legal systems in favour of defence procurement, the sector in which offsets remain the most popular, and where prohibitions in international and national laws do not apply. ${ }^{\mathrm{I}}$ This paper fills a critical gap in the academic legal literature by examining the mechanisms available in international law for controlling this serious impediment to international trade.

\section{OFFSETS AND THE WTO GOVERNMENT PROCUREMENT AGREEMENT}

\section{A. The Government Procurement Agreement}

The GPA is a plurilateral agreement, meaning that it is optional to the WTO's I 64 members. Currently there are seventeen parties to the GPA, comprising forty-five WTO members, twenty-eight of which are the Member States of the EU. A further twenty-nine WTO members participate in the GPA Committee as observers, ten of which are in the process of acceding to the Agreement. The steady but growing membership of the GPA reflects the potential for plurilateralism as a workable method of drawing more fields of economic governance into the international regulatory sphere of the WTO. However, its limited membership equally demonstrates the difficulty in achieving multilateral consensus over such a sensitive field of economic policy. Given the large role that governments play in many economies, the regulation of public procurement under international law remains highly contentious throughout the world.

The objective of the GPA is to liberalize government procurement markets among its signatory parties by eliminating discrimination against suppliers based on their nationality and by ensuring transparency in tendering procedures. This should facilitate competition for public contracts in goods and services on the basis of quality and price. The $1994 \mathrm{GPA}^{\mathrm{I} 5}$ (which itself was a revision of the $1979 \mathrm{GPA}^{\mathrm{I} 6}$ from the

\footnotetext{
I 2. Hoyos et al., supra note 9.

I3. Taylor, supra note I I at 32-3.

I 4. Dominik EISENHUT, "Offsets in Defence Procurement: A Strange Animal on the Brink of Extinction?" (2013) 38 European Law Review 393 at 394.

I 5. $\quad$ I994 GPA, supra note 2.

I6. Tokyo Round Code on Government Procurement, I2 April 1979 (entered into force January I98I), online: <https://www.wto.org/english/docs_e/legal_e/tokyo_gpr_e.pdf>.
} 
Tokyo Round of trade negotiations) was finalized in I994, but a revised version of the Agreement came into force in 20I4. Under the Revised GPA, ${ }^{17}$ parties undertake to engage in further negotiations in order to progressively reduce and eliminate additional discriminatory measures in order to expand the Agreement's coverage. According to the WTO itself, the WTO government procurement agreements are believed to facilitate procurement activities worth US\$I.7 trillion per year. ${ }^{\text {I8 }}$

The greatest weakness with the GPA as an instrument of regulating offsets, or indeed imposing rules on government procurement regulations of any kind, is its optional nature, covering less than one-fifth of the WTO's total membership. Moreover, even among the countries which have signed it, the GPA imposes incomplete coverage over public procurement activities because of the selective nature of its obligations. The GPA resembles the WTO's General Agreement on Trade in Services ${ }^{19}$ in that signatory parties only have to make the commitments they wish to, on a positive list basis. Covered procurement is listed for each signatory in a separate set of schedules, and non-listed sectors do not engage the Agreement's obligations. Parties need only commit to the particular governmental agencies and types of procurement contracts that are suited to their policy needs. Parties also set minimum monetary thresholds below which their procurement obligations will not apply, based on the International Monetary Fund's Special Drawing Right, a method intended to exclude procurement activities of small and medium-sized enterprises [SMEs]. Unfortunately, many GPA signatories omitted broad swathes of their procurement activities from the scope of their GPA commitments.

The GPA is subject to the WTO's Dispute Settlement System, and to date there has been one dispute brought through this system, which resulted in a panel report on the basis of the GPA. This dispute, Korea-Government Procurement, ${ }^{20}$ did not consider offsets but rather concerned a US complaint regarding the Korean government's procurement practices in relation to airport construction. The panel sided with Korea, ruling that its government had not made commitments under the GPA for the relevant procuring entities and consequently the GPA's rules were not engaged.

\section{B. Offset Prohibitions}

Although the Revised GPA has come into effect for most parties, the I994 GPA remains in force for those parties who are still in the process of ratifying the revised Agreement. The two versions of the GPA co-exist until all parties to the Agreement are bound by the revised Agreement. With respect to the obligations between a party to the

\footnotetext{
17. Revised Agreement on Government Procurement, 30 March $20 \mathrm{I} 2$ (entered into force 6 July 20I4), online: World Trade Organization <https:/www.wto.org/english/docs_e/legal_e/rev-gpr-94_oI_e.pdf> [Revised GPA].

I 8. "Agreement on Government Procurement" (March 20I6), online: World Trade Organization <https:// www.wto.org/english/tratop_e/gproc_e/gp_gpa_e.htm>.

I9. General Agreement on Trade in Services, I 5 April I994, I 869 U.N.T.S. I 83 (entered into force I January I995) [GATS].

20. Korea-Measures Affecting Government Procurement, WT/DS $6_{3} / \mathrm{R}$ (Panel Report circulated I May 2000).
} 
I994 GPA and a party to the Revised GPA, the I994 GPA will govern. Accordingly, the I994 GPA's treatment of offsets remains relevant.

To begin with, the 1994 GPA contains an interpretive note which provides a definition of offsets:

Offsets in government procurement are measures used to encourage local development or improve the balance-of-payments accounts by means of domestic content, licensing of technology, investment requirements, counter-trade or similar requirements. ${ }^{2 I}$

This section offers an indication of the types of measures which will be encompassed by the provision, and does so in a manner that focuses on the aims of the measure-local development and balance of payments equilibrium, respectively.

Most crucially, the I 994 GPA contains the following key provision which prohibits government entities from imposing offsets as a condition for the award of contracts:

Entities shall not, in the qualification and selection of suppliers, products or services, or in the evaluation of tenders and award of contracts, impose, seek or consider offsets. ${ }^{22}$

This straightforward injunction, capturing both the imposition of traditional offsets by governments as well as the less common proactive offering of offsets by firms in order to secure winning tenders is tempered by the next section exempting developing countries:

Nevertheless ... a developing country may at the time of accession negotiate conditions for the use of offsets, such as requirements for the incorporation of domestic content. Such requirements shall be used only for qualification to participate in the procurement process and not as criteria for awarding contracts. Conditions shall be objective, clearly defined and non-discriminatory ... and may include precise limitations on the imposition of offsets in any [procurement] contract ... The existence of such conditions shall be notified to the Committee and included in the notice of intended procurement and other documentation. ${ }^{23}$

Accordingly, under the 1994 GPA, there is broad scope for developing states to impose offsets subject to notification requirements. This exception to the offset prohibition is based on the "infant industry" rationale. Firms from developing countries cannot always compete effectively with those from the developed world, and the assistance of such preferences allows them to develop into mature market participants. ${ }^{24}$ So far this exception is of limited importance, however, given that there are currently no GPA signatories that classify as developing (with the arguable exceptions of Israel and Armenia).

The Revised GPA repeats the definition of offset found in the earlier Agreement (almost verbatim), although places it in the formal definition section of the Agreement. ${ }^{25}$ As in the 1994 GPA, the Revised Agreement prohibits offsets outright with the following

\footnotetext{
2I. $\quad$ I994 GPA, supra note 2, Interpretive Note 7.

22. Ibid., art. XVI(I).

23. Ibid., art. XVI(2).

24. Taylor, supra note II at 20-I.

25. Revised GPA, supra note $\mathrm{I} 7$, art. I(l).
} 
language: "With regard to covered procurement, a Party, including its procuring entities, shall not seek, take account of, impose or enforce any offset." ${ }^{26}$ There is also an exception for developing countries, with a similar proviso that the developing country imposing an offset must clearly state that an offset will be applied in the notice of intended procurement, and that it must be applied in a manner that does not discriminate among other signatories. ${ }^{27}$ In other words, should a developing country ever sign the GPA, it may impose offsets, as long as they do not favour goods or services from one signatory state over another one-effectively a most-favoured-nation limitation. Infant industry assistance should be used as a development tool, not as a means of according preferences based on political alliances between states, such as, for example, those based on former colonial ties. Given the scope of use of offsets permitted by developing countries, the Revised GPA's treatment of offsets may actually amount to somewhat of a relaxation of the rules on offsets compared to the earlier Agreement. The I994 GPA's requirement that offsets should be used only for qualification to participate in the procurement process and not as criteria for awarding contracts has been dropped. Put more simply, under the 1994 GPA a government body may not invite foreign suppliers to offer as high an offset obligation as they are able to and then award the tender to the supplier that offered the highest level of offset. Still, it is likely that even under the new GPA, conditions on how developing countries may use offsets will be negotiated along with its special treatment package with other GPA parties. ${ }^{28}$

As noted above, the GPA only embraces the sectors and thresholds chosen by the individual party, and if offsets are important to a particular purchasing entity they can remain, provided that this is stipulated in each party's commitments. With the offsets effectively removed from the policy toolkit of GPA signatories, party governments can instead choose to negotiate specific exceptions to this provision in the scope or coverage of their specific commitments as set out in the Annexes of the Agreement. Such exceptions tend not to be phrased using the word "offsets" but rather reference particular types of procurement for which local content preferences will be accorded. For example Canada's sub-central (provincial) commitments under the GPA excludes procurement that is intended to contribute to economic development of the various listed provinces and territories. ${ }^{29}$

Although the GPAs are subject to the WTO's Dispute Settlement System, a key feature of the GPA regime is that it further enshrines private firms' capacity to bring claims for breach of the Agreement's procurement rules by signatory parties directly against governments through mandatory domestic dispute settlement procedures. WTO procurement rules require signatory parties to maintain domestic judicial and administrative procedures through which the fairness of procurement bidding and tendering procedures, including offset prohibitions, may be challenged. In addition to the above-mentioned exceptions for developing countries, and the capacity for parties

\footnotetext{
26. Ibid., art. $\operatorname{IV}(6)$.

27. Ibid., art. $\mathrm{V}(3)(\mathrm{b})$.

28. Arie REICH, "The New Text of the Agreement on Government Procurement: An Analysis and Assessment" (2009) I 2 Journal of International Economic Law 989 at IOI4.

29. Canada GPA, annex 2, note 3, 23 June 20I4 (WT/Let/954).
} 
to exclude offsets from the coverage or scope of their procurement commitments, both GPA agreements contain exceptions for national security and general exceptions relating to public policy concerns.

As noted above, national defence is the chief economic sector in which procurement offsets have been traditionally used. The Revised GPA contains the following national security exception which is broadly similar to that contained in the 1994 GPA:

Nothing in this Agreement shall be construed to prevent any Party from taking any action or not disclosing any information that it considers necessary for the protection of its essential security interests relating to the procurement of arms, ammunition or war materials, or to procurement indispensable for national security or for national defence purposes. $^{30}$

There has been much academic debate on the use of national security-based exemptions in international economic law. Much of this centres around the possibility of abuse of the so-called self-judging nature of many of these provisions, such as the one found here. ${ }^{3 \mathrm{I}}$ Nevertheless, it is impossible to imagine a multilateral treaty, particularly one on procurement, which would not contain this type of carve-out. The vast majority of exemptions to offset rules have come from defence-oriented procurement. ${ }^{32}$

The GPA also contains a General Exception clause which uses similar wording to that of GATT I 994 Article XX. ${ }^{33}$ Accordingly, GPA parties could potentially justify their use of offsets where this is necessary to protect public morals, order, or safety, or human, animal, or plant life or health, and the protection of intellectual property. These interests are subject to the overall requirement, also taken from GATT XX, that the measures must not be applied in a manner that would constitute a means of arbitrary or unjustifiable discrimination. ${ }^{34}$ As there are no disputes in which these exceptions have been asserted by GPA parties, it is not clear how WTO panels will interpret these provisions in the context of procurement offsets. It is most likely that they will use GATT Article XX jurisprudence for guidance.

\section{OFFSET CONTROLS UNDER OTHER WTO INSTRUMENTS}

No other WTO instruments deal directly with procurement offsets, but the spirit of prevention of the distortive effects in local content rules can be detected in other spheres of WTO law, none of which would likely operate as a genuine legal barrier to their use. A consideration of these rules sheds some light on the highly sensitive nature of procurement as a special kind of economic activity that has been cautiously carved out from the WTO's disciplines.

\footnotetext{
30. Revised GPA, supra note I7, art. III(I).

3I. E.g. William BURKE-WHITE and Andreas VON STADEN, "Investment Protection in Extraordinary Times: The Interpretation and Application of Non-Precluded Measures Provisions in Bilateral Investment Treaties" (2008) 48 Virginia Journal of International Law 307.

32. Taylor, supra note I I at 2 I.

33. General Agreement on Tariffs and Trade, I 5 April I994, I 867 U.N.T.S. I 87 (entered into force I January I995) [GATT I994].

34. Ibid., art. III(2).
} 


\section{A. Performance Requirement Prohibitions}

While offsets operate as an impediment to international trade in goods and services, they may also act as obstacles to foreign direct investment in the sense that goods or services-based restrictions placed on foreign investors could impair a foreign firm's ability to enter or compete in the domestic market. In this sense, offsets are a subset of what are known as "performance requirements" - conditions placed on foreign firms by host states, and which require foreign firms to engage in certain conduct, for example to use a certain amount of local content. Performance requirements, although unrelated to public procurement, are a trade-distorting as well as FDI restrictive variety of offset. The similarity has not gone unnoticed by investment arbitration tribunals, which have even used the language of performance requirements when referring to government procurement offset provisions. ${ }^{35}$

The primary instrument under international law for controlling the use of performance requirements as imposed on foreign investors is the WTO's Trade-Related Investment Measures Agreement. ${ }^{36}$ This minimalistic agreement uses yet another term, "trade-related investment measures", to capture the types of conditions that can be associated with offsets, namely domestic content. Trade-related investment measures cover only goods-oriented conditions on foreign firms, not services. Although traderelated investment measures are not defined under the TRIMs, an illustrative list of types of these measures that are inconsistent with GATT's national treatment provisions (and which therefore violate Article 2.I of the TRIMs) are contained in an Annex to the Agreement. Generally speaking, these reflect the use of local goods, essentially the same policy objective as in many procurement offsets.

The illustrative list states that prohibited trade-related investment measures include those measures which are mandatory or enforceable under domestic law or under administrative rulings, or with which compliance is "necessary to obtain an advantage" ${ }^{37}$

Although the term "advantage" is not defined in the TRIMs, the Appellate Body in the Canada-Aircraft dispute noted that compliance with a trade-related investment measure in order to obtain an "advantage" under the TRIMs may contemplate forms other than a "financial contribution" or "benefit" (such as envisioned by the SCM, see further below). Moreover, no comparison with a market benchmark is required under the TRIMs for the purpose of ascertaining whether an advantage has been conferred, as in benefits under the SCM. ${ }^{38}$ Rather, "advantage" is understood to encompass all types of advantages, not simply public financial contributions. ${ }^{39}$ It is unclear whether the purchase of goods by a public authority would qualify as an advantage, but given that this constitutes a "benefit" under the $\mathrm{SCM}^{4 \circ}$ (see below), it is not difficult to imagine that a panel could reason so.

35. E.g. ADF Group Inc. v. USA, (9 January 2003) ICSID Case No. ARB(AF)/oo/I at [17I] (referring to art. IO06 of NAFTA).

36. TRIMs, supra note 3.

37. Annex I:I \& 2.

38. Canada-Measures Affecting the Export of Civilian Aircraft, WT/DS70/AB/R (Appellate Body Report adopted 20 August I999), at para. [5.208].

39. Michael DALY, "Investment Incentives and the Multilateral Agreement on Investment" (1998) 38 Journal of World Trade 5 at 17.

40. SCM, supra note 4 . 
In that sense the TRIMs could be viewed as an indirect means of controlling goods-based offset requirements imposed in conjunction with procurement. One of the problems with this possibility, however, is that the GATT's national treatment obligation (which is incorporated in the TRIMs through Article 2.I) expressly does not apply to procurement activities by governments or government agencies. ${ }^{4 \mathrm{I}}$

The national treatment provision of GATT was examined in the Canada-Feed-InTariff dispute, ${ }^{42}$ one of the few WTO cases dealing with the TRIMs. This dispute concerned the imposition of domestic content rules on solar- and wind-powered electricity providers in order for such providers to qualify for guaranteed prices under the Feed-in-Tariff [FIT] programme, in the Canadian province of Ontario. In addition to assertions of illegal subsidization (see further below), Japan and the EU contended that Canada's Feed-in-Tariff programme containing local content rules violated the national treatment obligation of Article III of the GATT and Article 2. I of the TRIMs Agreement (as a trade-related investment measure inconsistent with GATT's national treatment obligation). Canada claimed that the Feed-in-Tariff scheme entailed government procurement and therefore should be exempted under GATT Article III $(8)(\mathrm{a})$, which would in turn remove the measure from consideration under the TRIMs. Finding against Canada that the measure was a trade-related investment measure and a GATT-inconsistent local content requirement, the panel ruled that the scheme was not excluded from the coverage under GATT III( 8$)$ (a) because the government of Ontario's procurement of electricity under the FIT programme ${ }^{43}$ was undertaken with a view to commercial resale. In other words, it was outside the sphere of normal procurement activity where governments purchase goods and services for their own use. The Appellate Body confirmed this finding, also ruling that the relevant measure did not fit the GATT exception for public purchasing found in Article III(8)(a), and as such led to violations of both GATT Article III and TRIMs Article 2.I as prohibited local content rules. This decision appears to preclude the application of government procurement offsets to the TRIMs discipline. Had the electricity been for government use rather than for resale, the Article III(8)(a) procurement exception would have applied, thereby insulating the local content requirements from review under GATT Article III.

\section{B. Subsidies}

The WTO Agreement on Subsidies and Countervailing Measures ${ }^{44}$ controls the use of subsidies, effectively government assistance to private firms, because these are seen as market distortions which lead to inefficient allocation of resources and interfere with international trade in goods. While the SCM contains no express reference to either

\footnotetext{
4I. GATT 1994, supra note 33, art. III(8)(a).

42. Canada-Certain Measures Affecting the Renewable Energy Generation Sector [complainant Japan], $\mathrm{WT}_{\text {IDS }}$ I 2/R (Panel Report circulated I9 December 20I2), WT/DS4I2/AB/R (Appellate Body Report circulated 6 May 20I3); [complainant European Union], WT/DS426/R (Panel Report circulated I9 December 20I2), WT/DS426/AB/R (Appellate Body Report circulated 6 May 20I3) [Appellate Body Report].

43. Ontario government: online: <http://fit.powerauthority.on.ca/sites/default/files/version 5/FIT-5-O-IRules-2016092I.pdf $>$.

44. SCM, supra note 4 .
} 
offsets or public procurement, it does establish that the purchasing of goods (but not services) by governments may be considered a subsidy. ${ }^{45}$ While the definitions of "purchase" and "procurement" are arguably dissimilar, ${ }^{46}$ there is no WTO jurisprudence establishing whether or not this provision could encompass public procurement transactions. At first blush it seems at least plausible that "subsidy" could contemplate public procurement-the firm which wins the bid gains an advantage in that it secures a contract that is directly the result of government action. In an offset it is not the government's act of choosing the specific (domestic) supplier which confers the advantage, but rather the act of the supplying firm purchasing domestic inputs at the government's behest. The offset, as the proximate cause of the purchase, may therefore be conceived as an indirect or derived subsidy. Furthermore, the SCM clearly prohibits domestic content-based subsidies which are analogous to offsets. ${ }^{47}$ Taken together, these two features of the SCM appear to forbid offset-type measures in relation to the public procurement of goods. The difficulty with fitting public procurement and related offset obligations into the scope of the SCM's disciplines as illegal subsidies, however, lies in the additional requirements of benefit and specificity.

First and most importantly, the SCM is unlikely to capture traditional government procurement transactions (and in that sense restrict offsets) because of the understanding of "conferral of benefit" articulated in Article I4(d)). This Article states that:

the provision of goods or services or purchase of goods by a government shall not be considered as conferring a benefit unless the provision is made for less than adequate remuneration, or the purchase is made for more than adequate remuneration. The adequacy of remuneration shall be determined in relation to prevailing market conditions for the good or service in question) $\ldots{ }^{48}$

Clearly, then, public procurement cannot be considered a subsidy unless the governmental authority pays more or less than normal market conditions would dictate, neither of which would normally apply to offset arrangements, where the advantage is winning the contract, not being paid more to perform it. Putting aside for the moment that it is difficult to establish normal market conditions where there is traditionally one purchaser which is a government (for example infrastructure construction), recall that offset arrangements tend to add additional costs to the supply contract (in some cases more than fifty percent). But this is not what is meant by the "less than adequate remuneration", which contemplates that the firm receives goods or services from the government and does not pay the full price for them. Rather, an offset means that the supplying firm ends up being paid less than it should have been because of the burden of fulfilling the offset obligation. ${ }^{49}$ Therefore an offset would appear to preclude a

\footnotetext{
45. Ibid., art. I.I(a)(I)(iii).

46. See the Appellate Body's discussion in Canada-Feed-In-Tariffs, supra note 42 at [5.59] in relation to the use of the two words in GATT art. III(8)(a).

47. SCM, supra note 4 , art. 3.I(b).

48. Ibid., art. $14(\mathrm{~d})$.

49. Of course suppliers may often factor the cost of complying with the offset into the price they charge to the purchasing entity.
} 
finding that government procurement constituted an unlawful subsidy. In other words, offset-based procurements cannot be construed as subsidies precisely because they also impose costs on suppliers (the obligation to use local inputs or to engage in knowledge transfer), as well as the obvious benefit (that their goods are purchased by the government in the first place). Indeed, offsets illustrate the "other side of the ledger" that characterizes various subsidy arrangements, i.e. the often unacknowledged reality that many subsidy programmes also impose costs on private firms. ${ }^{50}$

Second, in order to qualify as a subsidy, measures must satisfy the requirement of specificity. ${ }^{5 \text { I }}$ It is unlikely that procurement subject to offsets would satisfy this criterion either. WTO jurisprudence has established that specificity will be found where the public body explicitly limits access to a subsidy to certain enterprises. ${ }^{52}$ In the context of an offset, this could mean that the purchase of goods (the subsidy) was available only to firms using local inputs. ${ }^{53}$ But this is not what was meant by "certain enterprises", as illustrated in the next subsection; specificity will not exist where there are, as Article 2.I (b) of the SCM puts it: "objective criteria or conditions governing the eligibility" for the subsidy [for example the use of local inputs], the "eligibility is automatic" [if they abide by the offset requirement they will be entitled to the subsidy], and that the "conditions are strictly adhered to" [no favouritism or bribes, etc.], which has been understood by the Appellate Body to indicate openness of access to the subsidy. ${ }^{54}$ These cumulative criteria, characterizing traditional offset procurement arrangements which are imposed not only on domestic firms but on all firms, would almost certainly remove them from the scope of the purview of the SCM.

The difficulty of bringing local content procurement rules into the scope of the SCM was also contemplated by the WTO panel and Appellate Body in the Canada-Feed-inTariff dispute, noted above. ${ }^{55}$ In addition to allegations of TRIMs violations, the complainants argued that Ontario's Feed-In-Tariff regime breached Article 3.I (b) of the SCM as a prohibited import substitution measure. While the panel concluded that the programme did amount to a financial contribution by the government as a purchase of goods, a majority of the panel dismissed the allegations that the challenged measures amounted to a subsidy under Article I.I(b) of the SCM on the basis that there was no benefit conferred on given suppliers as required under Article I4(d). This was because the relevant renewable energy market was not competitive; instead it was significantly controlled by government intervention, and as such it was impossible to determine whether the remuneration was adequate or not, as required by that section.

50. Alan O. SYKES, “The Economics of WTO Rules on Subsidies and Countervailing Measures" (2003) John M. Olin Law \& Economics Working Paper No. I86 (2nd Series) at 3.

5I. SCM, supra note 4 , art. I.2.

52. Ibid., art 2.I(a). See US-Anti-Dumping and Countervailing Duties (China), WT/DS379/AB/R (adopted 25 March 20II), where it was held at [373] that certain enterprises refers to "a single enterprise or industry or a class of enterprises or industries that are known and particularised".

53. As noted above, offsets more clearly subsidize the firms from which the local inputs are sourced rather than the firm which uses them in securing the procurement tender. If the number of these inputting firms is small, this could amount to a specific subsidy where such firms would otherwise be uncompetitive.

54. SCM, supra note 4 , art. 2.I(b). US-Ant-Dumping and Countervailing Duties (China), supra note 52 at [368].

55. Appellate Body Report, supra note 42. 
Put another way, traditional government procurement cannot be considered a subsidy, as it is understood in the SCM, because it is by definition outside normal market conditions. ${ }^{5}$ Such conditions occur, for example, where there is a significant degree of government purchasing in the relevant sector. The Appellate Body was unable to determine whether the challenged measures conferred a benefit on certain electricity suppliers and were therefore inconsistent with the SCM's disallowance of domestic content obligations. This was because there was no clear market benchmark with which to gauge adequate remuneration under Article I4(d).

The Canada-Feed-in-Tariff case demonstrates the unlikelihood that local content procurement rules could qualify as prohibited measures under the SCM, despite the fact that they afford an advantage to local industries. Although the SCM prohibits subsidies that are contingent on the use of domestic goods, a contested local content requirement must first be proven to confer a benefit within the meaning of the agreement, and it could not be established that Ontario's Feed-in-Tariff programme did confer a benefit on domestic wind and solar power manufacturers. This does not so much demonstrate a failing of the WTO panels and Appellate Body to rigorously apply SCM rules where government assistance has been provided, as some commentators have noted, ${ }^{57}$ but is better seen as a reflection of the fact that a meaningful market benchmark is difficult to establish for renewable energy, given the historic dominance governments have in this sector. ${ }^{58}$ More fundamentally, many industries in which there is a significant degree of government purchasing may be similarly affected, even where there is competitive transparent tendering. Identifying the illegitimacy of domestic content requirements in markets with heavy government participation, such as large-scale infrastructure, may illustrate precisely why the SCM agreement is ill-suited as an instrument to regulate the use of offsets.

\section{OFFSETS IN PROCUREMENT CHAPTERS OF REGIONAL TRADE AGREEMENTS}

Government procurement is a highly sensitive issue and remains poorly covered under RTAs relative to other spheres such as goods and services. The countries which have made the deepest procurement commitments in RTAs tend to be developed countries, notably the US, which has included a procurement chapter forbidding offsets in all of its RTAs. Canada and the EU have also demonstrated a willingness to embrace procurement including offset prohibitions in their trade agreements. As of 20II, forty-four percent of RTAs including government procurement chapters contained a prohibition on offsets as a basic rule. There is a clear correlation between

56. It could be accurately described as a "monopsony" - that is where there is only one purchaser and many suppliers.

57. Luca RUBINI, “Ain't Wastin' Time No More: Subsidies for Renewable Energy, the SCM Agreement, Policy Space and Law Reform” (2012) I 5 Journal of International Economic Law 525.

58. Robert HOWSE, "Post-Hearing Submission to the International Trade Commission: World Trade Law and Renewable Energy: The Case of Non-Tariff Measures" (2005) Renewable Energy and International Law Project 20. 
comprehensive procurement rules and the prohibition of offsets-those agreements which have detailed rules tend to also forbid offsets. ${ }^{59}$ It is somewhat surprising that the UNCITRAL Model $\mathrm{Law}^{60}$ on public procurement makes no reference to offsets whatsoever, effectively encouraging countries to retain their capacity to make use of this policy tool.

The North American Free Trade Agreement [NAFTA] ${ }^{6 \mathrm{I}}$ between Canada, the US, and Mexico contains an offset prohibition in its government procurement chapter. It closely resembles that of the GPA and reads as follows:

Each Party shall ensure that its entities do not, in the qualification and selection of suppliers, goods or services, in the evaluation of bids or the award of contracts, consider, seek or impose offsets. For purposes of this Article, offsets means conditions imposed or considered by an entity prior to or in the course of its procurement process that encourage local development or improve its Party's balance of payments accounts, by means of requirements of local content, licensing of technology, investment, counter-trade or similar requirements. ${ }^{62}$

In addition to essential security and various public policy exceptions along the lines of GATT XX, NAFTA allows offset-type conditions to be imposed in procurement in conjunction with "Joint Programs for Small Business" in order to foster support for this critical category of supplier. ${ }^{63}$ NAFTA also initially allowed Mexico to set aside half of its procurement in oil and electricity companies per year for domestic suppliers on a temporary basis, and also allowed mandatory local content in some construction projects, a recognition of the sensitivity of Mexico as the only developing country in the RTA. ${ }^{64}$

The Comprehensive Economic and Trade Agreement [CETA $]^{65}$ recently signed between Canada and the EU uses a definition of offset in its procurement chapter similar to that contained in the GPA, which is unsurprising given that both parties are GPA signatories. As with the GPA, the CETA prohibits the use of offsets outright. ${ }^{66}$ Given the deep procurement commitments contained in the CETA, ${ }^{67}$ this provision should be seen as a considerable achievement in eliminating the harmful effects of offsets. The CETA also contains national security exceptions ${ }^{68}$ which should facilitate

59. Robert ANDERSON, Anna C. MULlER, Kodjo OSE-LAH, Josefita P. DE LEON, and Philippe PELLETIER, "Government Procurement Provisions in Regional Trade Agreements" in Arrowsmith and Anderson, supra note 5 at 607.

6o. UNCITRAL Model Law on Public Procurement, A/Res/66/95, adopted by the UN General Assembly on 9 December 201 I.

6I. North American Free Trade Agreement, I7 December I992, 32 I.L.M. 289 (entered into force I January I994) [NAFTA].

62. Ibid., art. I006.

63. Ibid., art. IO2I.

64. Kamala DAWAR and Simon EVENETT, "A Case Study of Regionalism: the EC-CARIFORUM Economic Partnership" in Arrowsmith and Anderson, supra note 5 at 664.

65. Comprehensive Economic and Trade Agreement, August 20I4, online: EUR-Lex <http://eur-lex.europa. eu/legal-content/EN/TXT/?qid=I467909007204\&uri=COM:2016:443:FIN\#document2>.

66. Ibid., chapter X, art. VI.

67. Covering additional entities such as municipal governments and universities, see David COLLINS, "Globalized Localism: Canada's Government Procurement Commitments under the CETA" (20I6) Journal of Transnational Dispute Management I.

68. Art. I9.3(I). 
defence-oriented procurement as well as general exceptions ${ }^{69}$ covering a range of serious public policy issues.

The final text of the Transatlantic Trade and Investment Partnership [TTIP], still under negotiation between the US and the EU, will likely include a procurement chapter. Given recent treaty practice of the US and the EU, the procurement rules will probably resemble those of the GPA, with specific government agencies and procurement activities outlined in separate schedules or appendices. The EU is not expected to accord its most comprehensive procurement coverage to the US under the TTIP because it is dissatisfied with the level of procurement that the US offered through its GPA commitments. In contrast to the EU's desire for greater access to US procurement, firms in the US are generally satisfied with their access to procurement in Europe. ${ }^{70}$ The TTIP will almost certainly contain exemptions in relation to defence procurement and national security, most likely using standard self-judging language.

Public procurement tends to be entirely absent in African and Latin American RTAs, again likely reflecting the realities that preferential procurement remains an instrument of domestic development. Of significant concern is the unfortunate failure of many Asian RTAs to include comprehensive government procurement disciplines even among those nations which are accurately described as "emerging markets" with large public infrastructure budgets. Many Asian RTAs minimize or entirely omit government procurement provisions. The approach to procurement among Asia's large economies in particular (China, India, and Japan) has been accurately described as "cautious". ${ }^{\text {I }}$ Given the growing strength of many Asian economies and the need for sustained global integration in order to achieve further growth, as well as the obvious advantage of efficiency in public expenditure, commentators have urged that Asian states should include deeper government procurement commitments in their trade agreements. ${ }^{72}$

The feasibility of using offsets going forward has been significantly undermined by the highly anticipated Trans-Pacific Partnership [TPP], ${ }^{73}$ an economic integration agreement covering trade and investment that was recently concluded among twelve Pacific Rim countries: the US, Australia, Brunei Darussalam, Canada, Chile, Japan, Malaysia, Mexico, New Zealand, Peru, Singapore, and Viet Nam. Under its current membership (even lacking China and Korea), the TPP is the largest agreement in Asia to include government procurement commitments. Given that China, Korea, and others may ultimately join the TPP, the economic size of this agreement means that it will play a crucial role in setting the procurement standards for trade agreements in

\footnotetext{
69. Art. I9.3(2).

70. Stephen WOOLCOCK and Jean H. GRIER, "Public Procurement in the Transatlantic Trade and Investment Partnership Negotiations" (2OI5) Centre for European Policy Studies, Paper No. 2 in the CEPS-CTR project "TTIP in the Balance” and CEPS Special Report No. Ioo/ February 2015.

7I. Ganeshan WIGNARAJA, "PRC and India: Pursuing the Same Approach to Free Trade Agreements" Asia Pathways (24 October 20I2), online: Asia Pathways <http://www.asiapathways-adbi.org/20I 2/Io/>.

72. Jean H. GRIER, “A Key Element in TPP, Missed Opportunity in RCEP” Asia Pathways (3 March 20I4), online: Asia Pathways <http://www.asiapathways-adbi.org/20I4/o3/>.

73. Trans-Pacific Partnership, 4 February 2016, online: Medium <https://medium.com/the-trans-pacificpartnership $>[T P P]$.
} 
Asia going forward. ${ }^{74}$ The TPP's chapter on government procurement defines offsets using almost identical language to the Revised GPA. ${ }^{75}$ Most importantly, the TPP follows the GPA's lead by prohibiting the imposition of offsets for covered procurement by any party. ${ }^{76}$ The TPP also grants an exception for developing countries, subject to a notice requirement. ${ }^{77}$ The TPP's procurement chapter does contain its own WTO-style general exceptions, again identical to those of the Revised GPA, ${ }^{78}$ along with a self-judging national security provision, ${ }^{79}$ both of which could operate to facilitate offsets in limited circumstances. Interestingly, the TPP also allows parties to adopt temporary measures for the purposes of dealing with serious balance of payments or external financial difficulties, ${ }^{8 \circ}$ a provision which is lacking from the Revised GPA. Such circumstances could possibly justify procurement offsets provided that they are imposed on a most-favoured-nation basis and are no more onerous than necessary. Since offsets are defined in the TPP (as elsewhere) in part as measures having the aim of “improving a Party's balance of payments accounts", they appear to invite the use of this exception as a potential justification. The temporal limit on the balance of payments exception would be of little help in controlling offsets tied to a few lucrative tenders. Some further guidance on the type of offsets which would fit within the balance of payments exception may ultimately be disclosed through jurisprudence.

Some Asian RTAs have excluded government procurement entirely or used so-called "procurement-lite" provisions, which contain mostly vague statements regarding transparency and co-operation in procurement regulations without any discussion of offsets. The value of these provisions should not be understated, but they do little to control public procurement-based protectionism. India's RTA with Korea (known as CEPA) contains such pronouncements ${ }^{8 \mathrm{I}}$ and is the only Indian RTA that has any reference to procurement whatsoever. Despite the fact that China currently has observer status to the GPA, as well as obviously being of immense importance to the global economy (not to mention its massive public infrastructure budget), no Chinese RTAs contain comprehensive procurement chapters with offset restrictions. In keeping with the procurement-lite format, the China-Korea Free Trade Agreement does attempt to promote co-operation in the field of government procurement with a view to establishing a full agreement on procurement upon China's eventual accession to the GPA, ${ }^{82}$ but goes no further. The Singapore-Australia RTA (known as SAFTA) ${ }^{83}$ has

\footnotetext{
74. Grier, supra note 72.

75. TPP, supra note 73, art. I 5.I (4 February 2016) / GPA art. I.l.

76. Ibid., art. I 5.4(6) / GPA art. IV.6.

77. Ibid., art. I 5.5(I)(b) / GPA art. V.3.b.

78. Ibid., art. I 5.3 / GPA art. III.2.

79. Ibid., art. 29.2 / GPA art. III.I.

8o. Ibid., art. 29.3.

8I. Comprehensive Economic Partnership Agreement (CEPA), art. I3.I2 (7 August 2009). online: Indian government <http://commerce.nic.in/trade/india\% 2okorea \% 20cepa\% 202009.pdf >.

82. Arts. I7.I3, I7.I7 (I June 2015).

83. Singapore-Australia Free Trade Agreement (SAFTA) (28 July 2003), chapter 6, online: Australian government <http://dfat.gov.au/trade/agreements/safta/official-documents/Pages/default.aspx> (last accessed 3 November 2016).
} 
one of the most curious procurement chapters of all, which, despite being comprehensive in its detail (many of its provisions resemble those of the GPA), contains no mention of offsets whatsoever, suggesting that such arrangements remain vital economic instruments in these countries despite the fact that they are fully developed economies. Tellingly, this RTA expressly preserves the right of the Australian government to promote employment for significant indigenous communities as well as SMEs in its procurement contracts. ${ }^{84}$

Japan's practice with respect to offset prohibition is worthy of mention both because of its inconsistency and because Japan has significant influence in the region. While Japan is a signatory to the GPA, the Japan-ASEAN Comprehensive Economic Partnership Agreement, to take one example, lacks a procurement chapter altogether. ${ }^{85}$ The Japan-Mongolia Economic Partnership Agreement ${ }^{86}$ is a good example of a procurement-lite approach that neglects offsets. The Agreement simply requires parties to ensure that their procurement laws are transparent and fairly implemented, in addition to requiring parties to share information about their respective procurement regulations. ${ }^{87}$ It goes on to promise that parties will enter into further negotiations to establish a comprehensive chapter on government procurement once Mongolia expresses its intention to join the GPA. ${ }^{88}$ More progressively, Japan's Economic Partnership Agreement with Australia reiterates the GPA's prohibition on offsets in a dedicated provision ${ }^{89}$ evincing Australia's willingness to embrace GPA controls on a bilateral basis. Japan's Economic Partnership Agreement with Peru, a developing country and also a non-GPA signatory, also prohibits offsets. ${ }^{90}$ The procurement chapter of Japan's Economic Partnership Agreement with India prohibits discrimination in all procurement practices, but does not address offsets explicitly. Given that the discriminatory nature of offsets may be thought of as derivative (offsets do not grant advantages to domestic suppliers over foreign ones even though they do promote domestic industry at the expense of foreign ones), it is difficult to envision whether an offset obligation would be unlawful under that agreement. ${ }^{9 \mathrm{I}}$

84. Chapter 6, arts. I 5, I6 (28 July 2003). The EU-CARIFORUM RTA is perhaps even stranger; it contains a detailed procurement chapter with a definition of offset but no prohibition (art. I66.I7) (30 October 2008).

85. Agreement on Comprehensive Economic Partnership Among Japan and Member States of the Association of Southeast Asian Nations, I4 April 2008, online: Ministry of Foreign Affairs of Japan <http:// www.mofa.go.jp/policy/economy/fta/asean/agreement.pdf $>$.

86. Agreement Between Japan and Mongolia for an Economic Partnership, Io February 201 5, online: Ministry of Foreign Affairs of Japan <http://www.mofa.go.jp/files/oooo677I6.pdf>.

87. Ibid., arts. I3.I, I3.2.

88. Ibid., art. I3.3.

89. Agreement Between Australia and Japan for an Economic Partnership, 8 July 20I4, online: Australian Government-Department of Foreign Affairs and Trade <http://dfat.gov.au/trade/agreements/jaepa/ official-documents/Pages/official-documents.aspx>, art. I7.6.

90. Agreement Between Japan and the Republic of Peru for an Economic Partnership, 3 I May 20I I, online: Ministry of Foreign Affairs of Japan <http://www.mofa.go.jp/region/latin/peru/epa20IIO5/pdfs/ jpepa_ba_e.pdf $>$, art. I48.

91. Comprehensive Economic Partnership Agreement Between Japan and the Republic of India, I 6 February 20II, online: Ministry of Foreign Affairs of Japan <http://www.mofa.go.jp/region/asia-paci/india/ epa20I I 02/pdfs/ijcepa_ba_e.pdf>, arts. I I I, I I 5 . 
Finally, with respect to Asia's somewhat uneven position on offsets, something should be said of the Regional Comprehensive Economic Partnership [RCEP], ${ }^{92}$ which is a proposed RTA between the ten ASEAN members (Brunei Darussalam, Cambodia, Indonesia, Lao PDR, Malaysia, Myanmar, the Philippines, Singapore, Thailand, and Viet Nam) and the six countries with which ASEAN has RTAs (Australia, China, India, Japan, Korea, and New Zealand). This agreement is a major initiative in international economic integration and should carry much weight in guiding future policy. Unfortunately, it is unlikely that the RCEP will contain a government procurement chapter, let alone one which controls the use of offsets. This is despite the fact that two RCEP parties (Brunei Darussalam and New Zealand) are parties to the Trans-Pacific Strategic Economic Partnership Agreement [ $\mathrm{P}_{4}$ Agreement], which includes government procurement commitments including a prohibition on offsets. ${ }^{93}$

Generally speaking, the reluctance of developing countries to surrender the use of offsets as a policy tool may reflect their long-standing view that domestic content should be preserved in the special field of government procurement as an appropriate way to remain competitive in markets dominated by firms from the developed world. To a degree, this logic is supported by economic evidence. As noted above, studies have shown that certain types of offsets can be economically advantageous for less advanced countries. ${ }^{94}$ As such, it may be unwise for those countries seeking to gain a foothold in world markets to adopt blanket offset prohibitions in their RTAs, or else they should be willing to accept such rules only where there are exceptions for development purposes (as in the GPA).

As with the WTO TRIMs, the investment chapters of some RTAs as well as international investment agreements [IIAs] also prohibit performance requirements which, as noted above, resemble offsets. NAFTA presents a list of seven specific types of host state measures that the state cannot impose or enforce on foreign firms. These generally encompass domestic content type requirements, such as would be associated with an offset in the procurement context. These rules effectively recapture the prohibitions on trade-related investment measures found in the TRIMs, adding to them prohibitions relating to services. ${ }^{95}$ Importantly for the purposes of offsets, the tribunal in the investor-state arbitration ADF Group $v$. US ruled that NAFTA's performance requirements prohibitions do not extend to the treaty's government procurement rules, at least at the subnational level. The tribunal noted further that all three NAFTA members regularly imposed performance requirements as part of their national and sub-central government procurement regimes. ${ }^{96}$ This is despite the presence of the clear no-offset rule in the NAFTA, applying to all levels of government. ${ }^{97}$ This award seems to suggest, although unfortunately does not explain, that there is a clear divide between

\footnotetext{
92. Regional Comprehensive Economic Partnership, entered into negotiation November 2012.

93. Trans-Pacific Strategic Economic Partnership Agreement, I 8 July 2005 (entered into force 2016), online: New Zealand Foreign Affairs and Trade <https://www.mfat.govt.nz/assets/_securedfiles/FTAs-agreements-in-force/P4/Full-text-of-P 4 -agreement.pdf $>$, art. I I.6.

94. Taylor, supra note I I at 32-3.

95. NAFTA, supra note 6I, art. I Io6.

96. ADF Group Inc. $v$. USA, supra note 35 at [I88].

97. NAFTA, supra note 6I, art. Ioo6.
} 
performance requirements (which although prohibited under the NAFTA do not apply to procurement), and offsets (which are prohibited under the NAFTA but only apply to procurement).

Japan has included exacting performance requirement prohibitions in some of its new IIAs, such as the Japan-Myanmar Bilateral Investment Treaty of 20I3..$^{8}$ Generally speaking, modern RTAs between developing states (concluded within the last five years) tend not to include any reference to performance requirements in their investment chapters. Broad performance requirement prohibitions in IIAs are often referred to as TRIMs plus obligations because they encompass more measures than the domestic content-related investment measures contained in the TRIMs, sometimes including services or mandating knowledge transfer. Similar enlarged prohibitions are found in numerous RTAs containing investment chapters. ${ }^{99}$ Large emerging markets such as China and India have resisted prohibiting performance requirements in their IIAs. Given their importance as tools of development, it is unlikely that the large emerging markets would be willing to accept treaties denying their governments the use of these instruments as tools of development, ${ }^{\text {IOO }}$ other than merely affirming the TRIMs. There is limited arbitral case-law on performance requirement prohibitions in RTAs, ${ }^{\text {IOI }}$ none of which relates to procurement.

\section{CONCLUSION}

Offsets remain a common policy tool used by governments to ensure that the suppliers of procurement contracts contribute to the economy through domestic inputs, often raising the cost of contracts significantly without clear efficiency gains in terms of quality. Long associated with defence procurement, offsets are imposed by a number of governments, particularly in the developing world, in order to assist underperforming industries struggling with the rigours of globalization. The WTO has made progress in curtailing the use of offsets through a general prohibition in the GPA, but this agreement has selective coverage and currently has limited membership of countries that are almost exclusively developed, and for whom offsets are no longer vital policy tools, outside the narrow sphere of defence. Other than the GPA itself, the WTO agreements do not appear to be designed to restrain offsets in the context of procurement, although resistance to domestic preferences can be discerned in the TRIMs and the SCM as well as the GATT itself. These agreements disclose the WTO's focus on non-discrimination in the context of normal market conditions, which do not appear to embrace public

98. Japan-Myanmar Bilateral Investment Treaty, I 5 December $20 \mathrm{I}_{3}$ (entered into force 7 August 2014), online: Investment Policy Hub <http://investmentpolicyhub.unctad.org/Download/TreatyFile/3 II3>, art. 6 .

99. E.g. Korea-Australia FTA, I7 February 20I4, art. I I.9 (incorporating the same language as NAFTA).

Ioo. Muthucumaraswamy SORNARAJAH, "India, China and Foreign Investment" in Muthucumaraswamy SORNARAJAH and Jiangyu WANG, China, India and the International Economic Order (Cambridge: Cambridge University Press, 20IO), at I 5 I.

IоI. A few cases have been brought under NAFTA, e.g. Mobil Investments Canada Inc. and Murphy Oil Corporation v. Government of Canada ICSID Case No. ARB(AF)/o7/4, and ADF Group Inc. v. USA, supra note 35 . 
procurement by single purchasers engaging in contracts which favour suppliers using local inputs. Clearly exceptions in the GPA and RTAs for procurement preferences relating to national security, various public policy concerns along the lines of GATT XX, as well as those in favour of developing countries, were necessary to ensure that there would be sufficient support for open procurement rules taking into account domestic political pressures. As always, exceptions which are vaguely phrased or unevenly applied hold the potential for abuse for the purpose of according procurement advantages to domestic suppliers.

For their part, RTAs show an uneven treatment of offsets, with many developing countries declining to include offset prohibitions even in those agreements which contain procurement chapters, a policy choice that appears to suggest a strategy for coping with the fragile industries exposed to the pressures of global competition. It should come as no surprise that resistance to offsets is more prevalent in RTAs concluded by developed states where firms have greater capacity to operate in fully competitive markets. The reluctance of Asian states to embrace public procurement rules including offsets controls is particularly troubling given the growing economic influence of this region. Still, the TPP's duplication of the Revised GPA's procurement rules is an encouraging indication that open government purchasing, subject to reasonable limitations, is very much in the mindset of some Asian powers. Furthermore, until such time as the GPA expands its membership, or procurement chapters in developing country RTAs specifically address offset prohibitions, some of the harmful effects of these instruments can be mitigated by existing provisions on procurement transparency. To the extent that firms are compelled to fulfil offsets in order to win tenders, a clearer understanding of the nature of offset obligations could lessen some of the burden of any unanticipated domestic preference conditions.

If it is true that some kinds of offsets can be beneficial to the states that use them without imposing significant distortions on international trade, then it may be worthwhile to restructure offset prohibitions in international agreements in favour of more nuanced control, possibly along the lines of the SCM's so-called traffic light system. Under this approach, offset requirements that serve developmental goals and do not cause demonstrable injury along with serious prejudice to foreign industries could be permissible. ${ }^{\text {IO2 }}$ Offsets favouring domestic inputs should not necessarily be viewed as harmful in situations where foreign inputs were already inadequate or expensive. Clarification as to the type and extent of acceptable offsets could help deal with challenges to the TPP procurement chapter's exception for balance of payments problems, a provision which is disconcerting given that one of the purposes of offsets is often precisely to address these difficulties. Clear and reasonably tight rules on the use of this exception for offsets must be established. Second, given that offsets remain closely associated with defence-oriented procurement, it would be instructive to consider revising national security based exceptions in a manner that takes into account legitimate concerns while minimizing adverse trade impacts more effectively.

IO2. This approach has been recommended for performance requirements: see Robert EDWARDS and Simon LESTER, "Towards a More Comprehensive World Trade Organization Agreement on Trade-Related Investment Measures" (I997) 33 Stanford International Law Journal I69 at 203. 
Often all that is required to ensure national security in defence contracts is a degree of local oversight over the contract while still allowing most of the equipment to be sourced from abroad. ${ }^{103}$ Blanket exceptions for developing countries may require additional tailoring going forward, as this designation may be unjustified for largescale projects undertaken in some fast-growing emerging markets. ${ }^{\text {IO4 }}$

The uneven control of offsets under international law is problematic in as much as these instruments are understood to cause damaging distortions in trade as well as welfare losses to procuring governments overpaying for goods and services. This is worrisome because the use of offsets may be poised to intensify in step with enlarged public procurement as global spending on infrastructure by developing countries rises, bolstered by the support of development banks. Still, sizable procurement budgets tend to be associated with more economically advanced countries. Economic development is also closely linked to the presence of more mature markets consisting of domestic firms which are sufficiently robust to withstand competition and are therefore less needful of governmental assistance through offset protectionism. Accordingly, greater overall government procurement on a global scale may be counterbalanced by the diminished need for offsets, ultimately rendering their uneven regulatory control through the WTO and other international agreements in some senses redundant.

\footnotetext{
I03. Heuninck, supra note io at 35-6.

I04. As with special and differential treatment policies generally, see Sonia E. ROLLAND, Development at the WTO (Oxford: Oxford University Press, 2012) at 266-7.
} 